УДК 332.1

DOI: 10.14451/1.198.26

\title{
ВОЗМОЖНОСТИ РАЗВИТИЯ ОБРАБАТЫВАЮЩИХ ПРОИЗВОДСТВ НА ОСНОВЕ АНАЛИЗА ИСТОЧНИКОВ НАЛОГОВЫХ ДОХОДОВ
}

\section{(c) 2021 Булатова Елена Рашитовна}

аспирант кафедры экономики и управления предприятиями и производственными комплексами Санкт-Петербургский государственный экономический университет, Россия, Санкт-Петербург

E-mail: erb2401@gmail.com

\section{(c) 2021 Щербаковский Игорь Григорьевич}

магистрант второго года обучения

Санкт-Петербургский государственный экономический университет, Россия, Санкт-Петербург

E-mail:Gz@malthouse.ru

Проведен анализ основных налоговых доходов региональных бюджетов Российской Федерации и объемов отгруженных товаров, выполненных работ и услуг обрабатывающих производств. Сформулированы общие рекомендаций для исполнительных органов государственной власти по увеличению доходной части бюджетов.

Ключевые слова: Налоги, налог на прибыль организаций, налог на доходы физических лии, бюджет, Санкт-Петербург, Москва, Московская область, обрабатывающие производства, промышленность.

В современной науке среди основных функций государства в различных трактовках выделяют в том числе «налогообложение и взимание налогов» [4]. Посредством сбора налогов, пошлин и сборов формируется доходная часть бюджета для обеспечения выполнения своих «экономических, социальных и других функций» [5]. На основе необходимых расходов прогнозируются планируемые доходы. Это является экономической функцией государства [3]. Запланированные расходы и прогнозируемые доходы находят свое отражение в государственном бюджете. Трехуровневая иерархия Российской Федерации подразумевает трехуровневую бюджетную систему, и, следовательно, трехуровневую систему налогообложения, в соответствии с которой, налоги подразделяются на федеральные, региональные и местные.

На сегодняшний день в Российской Федерации насчитывается 15 налогов и сборов, из них 9 федеральных налогов (в том числе акцизы, государственная пошлина, сборы) и по три региональных и местных (включая сбор). Подробный перечень налогов и сборов приведен в статьях 13-15 Налогового Кодекса Российской Федерации (НК РФ) [1].

Целью данной работы является анализ основных налоговых доходов региональных бюджетов и формулирование рекомендаций для исполнительных органов государственной власти по увеличению доходной части бюджетов.
В соответствии со статьей 14 НК РФ к региональным налогам относятся [1]:

- налог на имущество организаций;

- налог на игорный бизнес;

- транспортный налог.

Федеральное законодательство устанавливает данный перечень налогов, а также верхние границы их размеров, позволяя регионам варьировать уровень налогообложения.

Несмотря на то, что ряд налогов, перечисленных ранее относится по классификации к федеральным, часть из них подлежит зачислению в бюджеты двух других уровней. Рассмотрим подробнее распределение между федеральным и региональным бюджетами налог на доходы физических лиц (НДФЛ), и распределение налога на прибыль организаций.

В общем случае налог на прибыль организаций составляет 20\%, из которых (абзац 3 статьи 284 НК РФ) [1]:

- $2 \%$ подлежит зачислению в федеральный бюджет (3\% в 2017-2024 годах);

- $18 \%$ в бюджет субъекта Российской Федерации (17\% в 2017-2024 годах), при этом субъект имеет возможность понижать ставку налога для отдельных категорий налогоплательщиков, но не более чем до 13,5\% (12,5\% в 2017-2022 годах).

В соответствии с Бюджетным кодексом Российской Федерации [2] (абзац 4 пункта 2 статьи 56 БК РФ) в бюджеты субъектов РФ подлежат зачислению 85\% НДФЛ. 
За основу проведенного в работе анализа были взяты данные о фактическом исполнении доходной части бюджетов субъектов Российской Федерации по состоянию на 01.01.2021 и 01.01.2020 [7].

В базе исследования использованы следующие данные о налоговых доходах бюджетов субъектов России:

- НДФЛ;

- Налог на прибыль организаций;

- Налоговые поступления от уплаты налогов по упрощенной системе налогообложения;

- Акцизы;

- Налоги на имущество физических лиц (для городов федерального значения: Москва, Санкт-Петербург, Севастополь);

- Налог на имущество организаций;

- Транспортный налог;

- Прочие налоговые доходы (в состав которых входит налог на игорный бизнес).

Наибольшее наполнение бюджетов в ряду вышеперечисленных налогов происходит за счет НДФЛ, а также налога на прибыль организаций. Так по результатам исполнения бюджетов субъектов Российской Федерации (по состоянию на 01.01.2021) доля налога на прибыль организаций в сумме с НДФЛ составила $68 \%$ всех налоговых и неналоговых доходов бюджетов. По состоянию на 01.01.2020 данное соотношение составило $69 \%$.

Рассмотрим подробнее исполнение бюджетов регионов России по состоянию на 01.01.2021.

Лидером по собираемости налоговых и не- налоговых доходов стала столица Российской Федерации - Москва. Поступления по данной статье составили более 2,5 трлн. рублей, из которых $71 \%$ - налоги на прибыль организаций и НДФЛ. На втором месте Санкт-Петербург - 616 млрд. рублей, из которых 77\% - налоги на прибыль организаций и НДФЛ. На третьем месте Московская область. Представим собранные данные по нескольким регионам с наибольшими и наименьшими налоговыми и неналоговыми доходами в Таблице 1.

В таблице 1 представлены доли объемов налога на прибыль организаций и НДФЛ в общем объеме налоговых и неналоговых доходов регионов. Как видно из Таблицы 1 в регионах с низким уровнем собираемости налогов доля НДФЛ значительно превышает долю налога на прибыль несмотря на весьма низкую численность населения в сравнении с регионами-лидерами. Прежде всего, стоит учитывать факт начисления в достаточно большом ряде регионов районного индексирующего коэффициента, который напрямую влияет на общие показатели собираемости НДФЛ. Так, например, в Республике Алтай данный коэффициент, начисляемый на оклад работника до вычета налога, составляет 1,4, а в Красноярском крае (за исключением части территории) этот коэффициент равен 1,3. Данные коэффициенты искажают исследование, поэтому в анализе будут использованы наиболее значительные различия и обобщенные выводы.

В регионах-лидерах рейтинга из Таблицы 1 первые две строчки занимают города федераль-

Таблица 1. Налоговые и неналоговые доходы, доли основных налоговых доходов и численность экономически активного населения субъектов России по состоянию на 01.01.2021

\begin{tabular}{|c|c|c|c|c|c|}
\hline $\begin{array}{c}\text { Пози- } \\
\text { ция }\end{array}$ & Наименование региона & $\begin{array}{c}\text { Налоговые и } \\
\text { неналоговые } \\
\text { доходы, тыс. } \\
\text { руб. }\end{array}$ & $\begin{array}{c}\text { Доля налога на } \\
\text { прибыль орга- } \\
\text { низаций,\% }\end{array}$ & НДФЛ,\% & $\begin{array}{c}\text { Численность } \\
\text { экономиче- } \\
\text { ски активного } \\
\text { населения по } \\
\text { состоянию на } \\
29.02 .2020, \text { в } \\
\text { тыс. чел. }\end{array}$ \\
\hline 1 & Москва & 2580292779 & 31 & 45 & 7248 \\
\hline 2 & Санкт-Петербург & 616588962 & 28 & 49 & 3055 \\
\hline 3 & Московская область & 510339294 & 33 & 37 & 4143 \\
\hline 4 & $\begin{array}{l}\text { Ханты-Мансийский автоном- } \\
\text { ный округ }\end{array}$ & 234119965 & 42 & 22 & 917 \\
\hline 5 & Красноярский край & 229740445 & 47 & 25 & 1491 \\
\hline \multicolumn{6}{|l|}{$\ldots$} \\
\hline 83 & Республика Алтай & 5897197 & 19 & 31 & 96 \\
\hline 84 & Республика Тыва & 5688075 & 8 & 55 & 127 \\
\hline 85 & Республика Ингушетия & 4028143 & 9 & 47 & 249 \\
\hline
\end{tabular}


ного значения, демонстрирующие превышение доли НДФЛ над долей налога на прибыль. Разница составляет для Москвы 14\%, для СанктПетербурга 21\%, а для Московской области только 4\%. Регионы, занявшие 4 и 5 позиции, демонстрируют превышение доли налога на прибыль организаций над НДФЛ.

Составим аналогичную таблицу по данным на 01.01.2020 (Таблица 2).

По состоянию на 01.01.2020 4-е место по уровню исполнения бюджета в части налоговых и неналоговых доходов заняла Республика Татарстан. Изменилась тройка регионов с наименьшим исполнением по налоговым и неналоговым доходам: Республика Ингушетия также на последней позиции, Республика Алтай и Калмыкия заняли 83 и 84 позиции.

Рассмотрим соотношения долей налоговых доходов Республики Калмыкия также за последующий период 01.01.2021: доля налога на прибыль организаций составила 33\%, доля НДФЛ $23 \%$.

Превышение доли НДФЛ над долей налога на прибыль в городах-лидерах рейтинга подтверждается выборкой в 2 года. Разница НДФЛ и налога на прибыль составляет для Москвы 7\%, для Санкт-Петербурга 14\%, а для Московской области также как и в таблице 1-4\%. Регионы, занявшие 4 и 5 позиции, также демонстрируют превышение доли налога на прибыль организаций над НДФЛ.

Дополнительно проведенный анализ данных объема отгруженных товаров собственного производства, выполненных работ и услуг собственными силами по субъектам Российской Федерации за 2020 год по обрабатывающим производствам в регионах-лидерах таблицы 1 и таблицы 2 представлен в таблице 3 [6].

Объем обрабатывающего производства по итогам 2020 года в Московской области превысил тот же показатель по Санкт-Петербургу. Обратимся к разнице в долях НДФЛ и налога на прибыль организаций в этих регионах (таблица 4).

Основываясь на данных таблиц 1, 2, 3 и 4 можно отметить, что Санкт-Петербург, получая больше налоговых и неналоговых доходов чем Московская область, производит меньше товаров, работ и услуг. При этом разница между уровнем поступлений от налога на прибыль

Таблица 2. Налоговые и неналоговые доходы, доли основных налоговых доходов и численность экономически активного населения субъектов России по состоянию на 01.01.2020

\begin{tabular}{|c|l|l|l|l|l|}
\hline $\begin{array}{c}\text { Пози- } \\
\text { ция }\end{array}$ & Наименование региона & $\begin{array}{c}\text { Налоговые и } \\
\text { неналоговые до- } \\
\text { ходы, тыс. руб. } \\
\text { Доля налога на } \\
\text { низаций, }\end{array}$ & $\begin{array}{c}\text { Численность } \\
\text { экономиче- } \\
\text { ски активного } \\
\text { населения по } \\
\text { состоянию на } \\
29.02 .2020, \text { в тыс. } \\
\text { чел. }\end{array}$ \\
\hline 1 & Москва & 2558210936 & 34 & 41 & 7248 \\
\hline 2 & Санкт-Петербург & 609599188 & 31 & 45 & 3055 \\
\hline 3 & Московская область & 498488725 & 33 & 37 & 4143 \\
\hline 4 & Республика Татарстан & 249489987 & 45 & 22 & 2031 \\
\hline 5 & Красноярский край & 248886823 & 53 & 21 & 1491 \\
\hline 8 & & & & 23 & 138 \\
\hline 84 & Республика Калмыкия & 5872477 & 41 & 38 & 96 \\
\hline 85 & Республика Ингушетия & 3248287 & 13 & 54 & 249 \\
\hline
\end{tabular}

Таблица 3. объем отгруженных товаров собственного производства, выполненных работ и услуг собственными силами по субъектам Российской Федерации за 2020 год, млн. руб.

\begin{tabular}{|c|l|c|}
\hline Позиция & \multicolumn{1}{|c|}{ Наименование региона } & Обрабатывающие производства \\
\hline 1 & Москва & 5945614 \\
\hline 2 & Московская область & 3012337 \\
\hline 3 & Санкт-Петербург & 2309864 \\
\hline
\end{tabular}


Таблица 4. разница в долях налога на прибыль организаций и НДФЛ,\%

\begin{tabular}{|l|c|c|}
\hline \multicolumn{1}{|c|}{ Наименование региона } & $\begin{array}{c}\text { Разница по данным на } \\
01.01 .2020, \%\end{array}$ & $\begin{array}{c}\text { Разница по данным на } \\
01.01 .2021, \%\end{array}$ \\
\hline Москва & 7 & 14 \\
\hline Московская область & 4 & 4 \\
\hline Санкт-Петербург & 14 & 21 \\
\hline
\end{tabular}

организаций и НДФЛ у Санкт-Петербурга значительно серьезнее чем у Московской области.

Не анализируя показатели по всем 85 регионам России, а основываясь на элементах выборки, представленных в таблице 1 и таблице 2, заметна значительная разница в соотношениях источников налоговых доходов регионов. Рассмотрим их более детально.

Основываясь лишь на двух календарных периодах заметно, что ряд регионов демонстрирует превышение доли НДФЛ над долей налога на прибыль организаций, а в ряде регионов ситуация противоположна.

Налог на прибыль организаций напрямую зависит от прибыльности деятельности юридических лиц, зарегистрированных на той или иной территории.

Количество зарегистрированных юридических лиц напрямую не влияет на объем поступлений налога на прибыль организаций, так как организации могут работать не только с прибылью, но и при ее отсутствии.

Различные кризисные явления в экономике региона, страны или мира приведут к резкому снижению данных показателей. Прежде всего будет наблюдаться снижение налоговых поступлений от прибыли организаций, а затем и снижение количества юридических лиц. Соответственно в условиях растущей экономики будет наблюдаться противоположных эффект.

НДФЛ строго фиксирован и выплачивается работодателем (наиболее популярный вариант уплаты налога) ежемесячно и по фиксированной ставке в $13 \%$. В случае наступления кризисных явлений следом, или параллельно со снижением прибыли организации, начнет снижаться и уровень уплаченного НДФЛ. Однако данный процесс в общем случае будет происходить с небольшим лагом в зависимости от ситуации в экономике. Даже фиксируя снижение прибыли организации не будут сразу проводить сокращения штата сотрудников, а значит уплата НДФЛ будет производиться в неизменном объеме некоторый период. Часто можно наблюдать ситуацию, при которой организации не фиксируют значительную прибыль достаточно продолжительное время, но при этом они обязаны выплачивать НДФЛ за своих сотрудников.

Анализируя НДФЛ, также стоит обратить внимание и на то, что отдельного внимания заслуживают органы государственной власти, финансируемые за счет бюджетных средств и, соответственно, не приносящие прибыль. Они также, как и частные юридические лица обязаны осуществлять выплату НДФЛ за своих сотрудников.

В случае растущей экономики НДФЛ будет расти, во-первых, за счет увеличения оплаты труда сотрудников, во-вторых, за счет найма дополнительных сотрудников.

При условии неизменности НК РФ субъекты РФ на данный момент составляют свои бюджеты основываясь на прогнозируемых показателях доходности. Каждый субъект РФ в целях увеличения доходной части бюджета заинтересован в повышении результативности работы, развитии и расширении организаций, зарегистрированных на территории субъекта. Дополнительный интерес для увеличения доходной части бюджета представляет увеличение количества юридических лиц, фиксирующих прибыль, а также увеличение числа официально работающего населения.

Особенностью начисления НДФЛ является тот факт, что налоговым агентом по начислению и уплате НДФЛ является работодатель. Уплата, соответственно, учитывается по месту регистрации юридического лица, следовательно, НДФЛ подлежит зачислению в тот бюджет, где зарегистрирована организация.

Исходя из того, что ставка НДФЛ строго фиксирована и работодатель оплачивает его вне зависимости от наличия прибыли, то показателем экономического роста юридических лиц является, прежде всего, наличие прибыли и, следовательно, фиксация уплаты налога на прибыль организаций.

По результатам проведенного анализа долей НДФЛ и налога на прибыль организаций в общем объеме налоговых и неналоговых доходов бюджетов субъектов России можно сделать сле- 
дующие выводы:

1. В среднем по России налоговые и неналоговые доходы бюджетов субъектов РФ более чем на половину состоят из НДФЛ и налога на прибыль организаций. Большая часть не нефтедобывающих регионов зависит от обрабатывающих производств.

2. Исходя из высокой зависимости бюджетов большинства субъектов от уровня поступления налогов от прибыли организаций и НДФЛ исполнительные органы государственной власти субъектов РФ должны быть заинтересованы в наращении доходов тех организаций, которые зарегистрированы на территории субъекта РФ, а также в прибыльности деятельности данных организаций и в увеличении числа официально работающего населения в данных организациях. Основная сфера (не относящаяся к нефтегазовым), приносящая в бюджеты наибольший доход - обрабатывающие производства, следовательно - промышленность.

3. В общем случае наиболее предпочтительным для субъекта РФ является превышение доли поступлений от налога на прибыль организаций над уровнем НДФЛ, а значит и выработка региональных инструментов поддержки организаций.

\section{Библиографический список}

1. Налоговый кодекс Российской Федерации (часть первая) от 31.07.1998 № 146-ФЗ (ред. от 17.02.2021) // «Собрание законодательства РФ», № 31, 03.08.1998, ст. 3824.

2. Бюджетный кодекс Российской Федерации от 31.07.1998 № 145-ФЗ (ред. от 30.04.2021) «Собрание законодательства РФ», 03.08.1998, N 31, ст. 3823.

3. Балаев С.А. Общетеоретическая модель механизма реализации функции налогообложения российского государства: понятие и основные элементы // Правовая политика и правовая жизнь. 2016. № 1. С. $114-118$. https://www.elibrary.ru/item.asp?id=30735421 (дата обращения: 12.05.2021).

4. Бардышева В.С.Налогообложение и взимание налогов как функция государства // Инновационная наука. 2016. № 6-3. URL: https://cyberleninka.ru/article/n/nalogooblozhenie-i-vzimanie-nalogov-kak-funktsiyagosudarstva (дата обращения: 12.05.2021).

5. Баймухаметова Аягюль Сериковна Теоретические воззрения на налоги как обязательные платежи в доход государства // ПУФ. 2017. № 2 (26). URL: https://cyberleninka.ru/article/n/teoreticheskie-vozzreniya-na-nalogikak-obyazatelnye-platezhi-v-dohod-gosudarstva (дата обращения: 12.05.2021).

6. Промышленное производство [Электронный ресурс] / Официальный сайт Федеральной службы государственной статистики URL: https://rosstat.gov.ru/enterprise_industrial (дата обращения: 12.05.2021).

7. iMonitoring [Электронный ресурс] // НПО «КРИСТА»._ URL: https://www.iminfin.ru/areas-of-analysis/budget (дата обращения: 12.05.2021). 